\title{
Effect of Using Two Different Types of Carbon Nanotubes for Blackberry (Rubus adenotrichos) in Vitro Plant Rooting, Growth and Histology
}

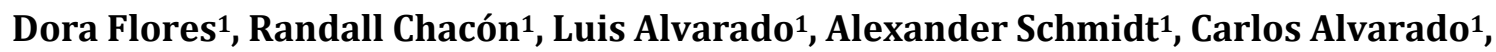 \\ Juan Chaves ${ }^{2}$ \\ ${ }^{1}$ Centro de Investigación en Biotecnología, Instituto Tecnológico de Costa Rica, Cartago, Costa Rica \\ ${ }^{2}$ Laboratorio de Nanotecnología, Instituto Tecnológico de Costa Rica, Cartago, Costa Rica \\ Email: dflores@itcr.ac.cr
}

Received 25 September 2014; revised 22 October 2014; accepted 7 November 2014

Copyright (C) 2014 by authors and Scientific Research Publishing Inc.

This work is licensed under the Creative Commons Attribution International License (CC BY).

http://creativecommons.org/licenses/by/4.0/

(c) (i) Open Access

\begin{abstract}
Nanoparticles are able to interact with biomolecules, creating functional nanosystems for transportation within in vivo cells, and leading to the study of their potential applications in the field of plant biotechnology. Therefore, the aim of this research was to determine the growth and rooting effect of functionalized (SWCNTs-COOH) and non-functionalized nanoparticles with iron residue inner particles (SWCNTs-Fe) in blackberry (Rubus adenotrichos) in vitro plants. Two types of SWCNTs were used, both of them characterized in a solid sample through Raman spectroscopy $(\lambda=$ $532 \mathrm{~nm}$ ) showing differences in the G band between SWCNT + Fe and SWCNT + COOH. The in vitro plants (approximately $15 \mathrm{~mm}$ length) were inoculated in a rooting medium. Six treatments were established: 4, 8, $12 \mu \mathrm{g} / \mathrm{ml}$ for each type of SWCNTs and a control without nanotubes. The assessed variables consisted of the average number of days for root emergence, average number of roots per plant, average root length per plant and the average stem length. This study determined that, in general, the SWCNTs-COOH promoted the growth of the in vitro plants under this assay, when compared to the SWCNTs-Fe trials. The lowest SWCNTs-COOH dose evidenced the best results for the assessed variables. Additionally, the histological analysis also evidenced that the plants treated with SWCNTs-COOH nanotubes $(4 \mu \mathrm{g} / \mathrm{ml})$ increased their cellular metabolism when compared to the control group.
\end{abstract}

\section{Keywords}

Single Walled Carbon Nanotubes, Growth, Rooting, Blackberry, TEM 


\section{Introduction}

Generally, the effect of nanoparticles in plants varies according to their composition, size, physical and chemical properties, as well as the plant species the nanoparticles interact with; producing enhancing or inhibitory effects on their growth in the different development stages [1].

Among nanoparticles, carbon nanotubes (CNTs) present different physical and chemical characteristics, including length, diameter, atomic configuration, impurities, defects and functionality, which allow them to have wide-ranging conductivity, tension strength, flexibility, and chemical reactivity properties. The CNTs structures can consist of a single layered cylinder, also known as single walled carbon nanotubes (SWCNTs); it can be comprised of two layers, being double-walled carbon nanotubes (DWCNTs); or it may contain multiple layers, which are called multi-walled carbon nanotubes (MWCNTs) [2].

These physical and chemical features of carbon nanomaterials have been used in agriculture to increase the crop yield, mainly in the germination process, root growth, and photosynthesis. However, many other plant interaction mechanisms exist, including absorption, accumulation, transport, or rejection of the nanoparticles; which have not been fully studied. Hence, despite the rapid progress in the development of this technology, the results obtained from its application have been very divergent [3]. Nonetheless, it has been established that the use of MWCNTs can induce the production and accumulation of oxygen reactive species, decrease the dry weight, chlorophyll content, as well as the activity of the peroxide dismutase enzyme. This effect is opposite to the results obtained functionalized or non-functionalized SWCNTs, which have demonstrated positive effects on root development; with the functionalized CNTs evidencing the least toxicity effects [4] [5].

Therefore, the aim of this research was to determine the effect of functionalized (SWCNTs-COOH) and non-functionalized (SWCNTs with iron residues) nanoparticles in the growth, rooting, and histology of blackberry (Rubus adenotrichos) in vitro plants.

\section{Methodology}

\subsection{Raman Spectroscopy for CNTs Characterization}

The study was performed with two types of nanotubes, Single Walled Carbon Nanotubes functionalized with a carboxyl group (SWCNTs-COOH) (90wt\% 1 - 2 nm outer diameter, 0.5 - $2.0 \mu \mathrm{m}$ length Cheaptubes Inc.) and non-functionalized Single Walled Carbon Nanotubes with iron residues in their interior (SWCNTs-Fe) (Obtained by HiPCO 90wt\%, 3.5 - 4.0 nm outer diameter, previously used by Flores et al., [6] and Mangir et al., [7] for biological applications). These nanotubes were characterized using the Raman DRX Thermo Scientific equipment (Solid sample, $\lambda=532 \mathrm{~nm}$ ).

\subsection{Bioassays with SWCNTs-COOH and SWCNTs-Fe}

Blackberry in vitro plants, with a length of approximately $15.0 \mathrm{~mm}$ and reproduced at Centro de Investigación en Biotecnología (CIB, for its acronym in Spanish) were used for this study. The plants were inoculated in a rooting culture medium developed by Flores et al. [8] with certain modifications, consisting of a M \& S (1962) medium at 50\%, supplemented with $3.5 \mathrm{~g} / \mathrm{L}$ of phytagel and $3 \%$ sucrose; evaluating three concentrations of SWCNTs-COOH, at $4 \mu \mathrm{g} / \mathrm{ml}, 8 \mu \mathrm{g} / \mathrm{ml}$ and $12 \mu \mathrm{g} / \mathrm{ml}$, and a control. The same conditions were used for the trial using SWCNTs-Fe.

The media were dispensed in $150 \mathrm{ml}$ glass flasks (20 ml of medium/flasks) and the number of plant segments was of two nodal sections per flask. The in vitro plants were incubated at 16 hours of light photoperiod and a temperature of $22^{\circ} \mathrm{C} \pm 2^{\circ} \mathrm{C}$.

The variables evaluated were the average number of days for root emergence, the average number of roots per plant, the average root length per plant, and the average length of the stem. The sample consisted of 45 explants per treatment and the information generated was analyzed through the General Linear Model (GLM) (p = 0.05) for the analysis of variance and Welch's ANOVA $(\mathrm{p}=0.05)$, using Minitab16 ${ }^{\circledR}$ statistical software.

\subsection{Histological Analysis}

In order to analyze and compare the ultrastructure of the plants' vascular system, five $0.3 \mathrm{~mm}$ stem samples of different control plants and another five plant samples from the best resulting SWCNTs treatment were used after a month of acclimation. In both cases, the samples were taken from the stem's mid-section. 
The procedure described by Çağlayan et al. [9], also used with certain modifications, by Elbeaino et al. [10] and Castellano et al. [11] was used for the sample processing. These methods are based on a standard protocol for biological samples; consisting of chemical fixation, washing, dehydration at increasing concentrations of acetone, resin embedment and polymerization. Sections of $70 \mathrm{~nm}$ were obtained using an ultramicrotome (Leica EM UC7 ${ }^{\circledR}$ ), which were placed in a 200 mesh copper grid and were dyed with uranyl acetate. For the sample analysis, a JEM-2100F ${ }^{\circledR}$ transmission electron microscope (TEM) was used.

\section{Results and Discussion}

\subsection{Raman Spectroscopy for CNTs Characterization}

Figure 1 presents the Raman spectra generated from the solid sample, and used for the characterization of the two types of CNTs tested. Through it, it was possible to find differences in the G band which are distinctive in the $\mathrm{C}=\mathrm{C}$ bonds and allows to differentiate the metallic CNTs with semi-conductive behavior [12] [13]. For the SWCNTs-COOH, it was only possible to observe a band associated to $\mathrm{G}+\left(1572.4 \mathrm{~cm}^{-1}\right)$ and the low frequency G- band was not determined clearly. On the other hand, SWCNTs-Fe presented the G+ $\left(1584.9 \mathrm{~cm}^{-1}\right)$ band as well as the $\mathrm{G}^{-}\left(1537.7 \mathrm{~cm}^{-1}\right)$ band with a double peak, which is a typical indication of single layered metallic carbon nanotubes [14]. The differences between the theoretical values for these CNTs and the ones observed could be related to the temperature, intensity, as well as the incidence angle of the beam over the sample [12].

\subsection{Bioassays with SWCNTs-COOH and SWCNTs-Fe}

It was determined that, the SWCNTs-COOH favored the in vitro plant growth when compared to the SWCNTs-Fe assay; however, the statistical analysis established that there were no significant differences for the interaction $(p>0.05)$ between the type of nanotube and the evaluated concentrations. In regards to the Main Factor Analysis, the treatment with the best values for the evaluated variables was SWCNTs-COOH in the lowest dose $(4 \mu \mathrm{g} / \mathrm{ml})$. Under this treatment, the roots developed in the shortest time (24.32 \pm 6.09 average days) being statistically different from the rest of the treatments $(\mathrm{p}<0.05)$, including the control. Moreover, this treatment presented the highest number of roots per plant ( $8.60 \pm 5.75$ roots), being comparable only to the treatment with $12 \mu \mathrm{g} / \mathrm{ml}$ of SWCNTs-COOH and the control (Figure 2(a) and Figure 2(b)). Considering the average length of the roots per plant, the best assay results were obtained with SWCNTs-Fe $(0.96 \pm 0.44 \mathrm{~cm})$ (Figure 3(a)). The highest average length stem was achieved with $4 \mu \mathrm{g} / \mathrm{ml}$ of SWCNTs-COOH $(2.40 \pm 0.66 \mathrm{~cm})$ (Figure 3(b)).

In general, the application of SWCNTs-COOH was beneficial to the growth parameters evaluated. It was possible to prove that the effect is dependent on the concentration, where plants dosed with low concentrations of CNTs can have positive effects on seed germination, root development and water transport within the plant, or no evidence of phytotoxicity; contrary to the negative effects that can be produced by high dose trials [2] [15]. Various studies report growth promotion on plants in contact with CNTs. Cañas et al. [4] exposed cabbage, car-

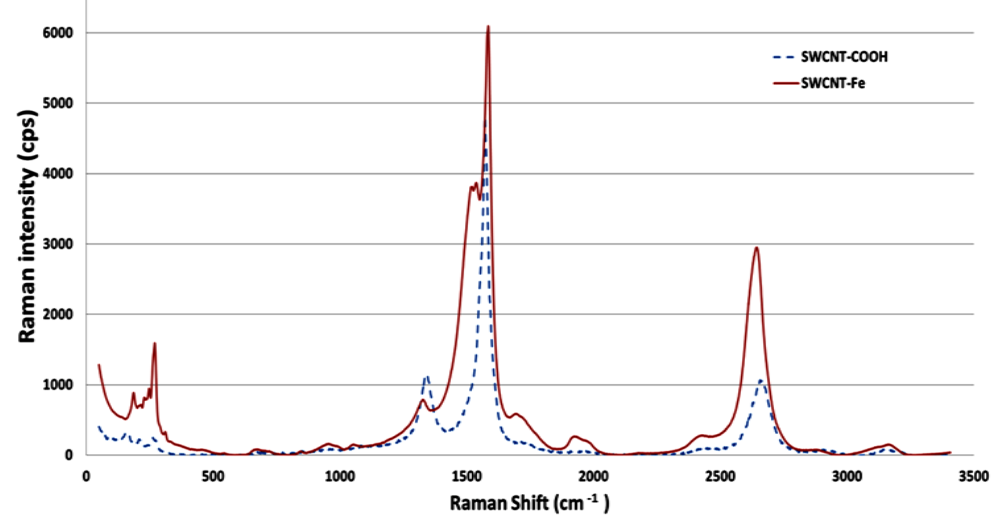

Figure 1. Raman spectra for the SWCNT characterization. Source: Centro de Investigación en Biotecnología ITCR. 


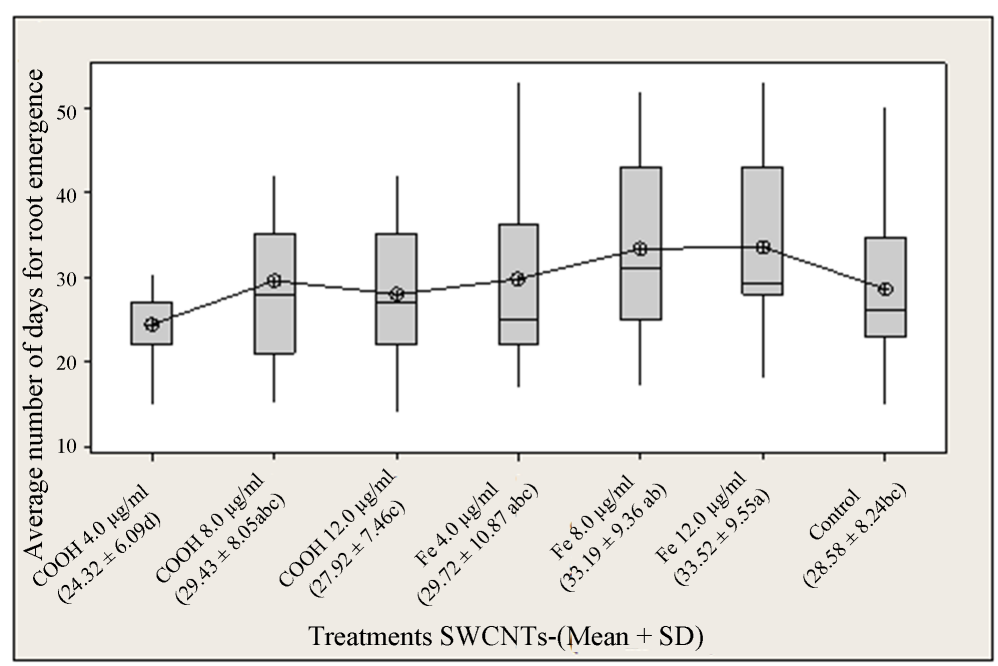

(a)

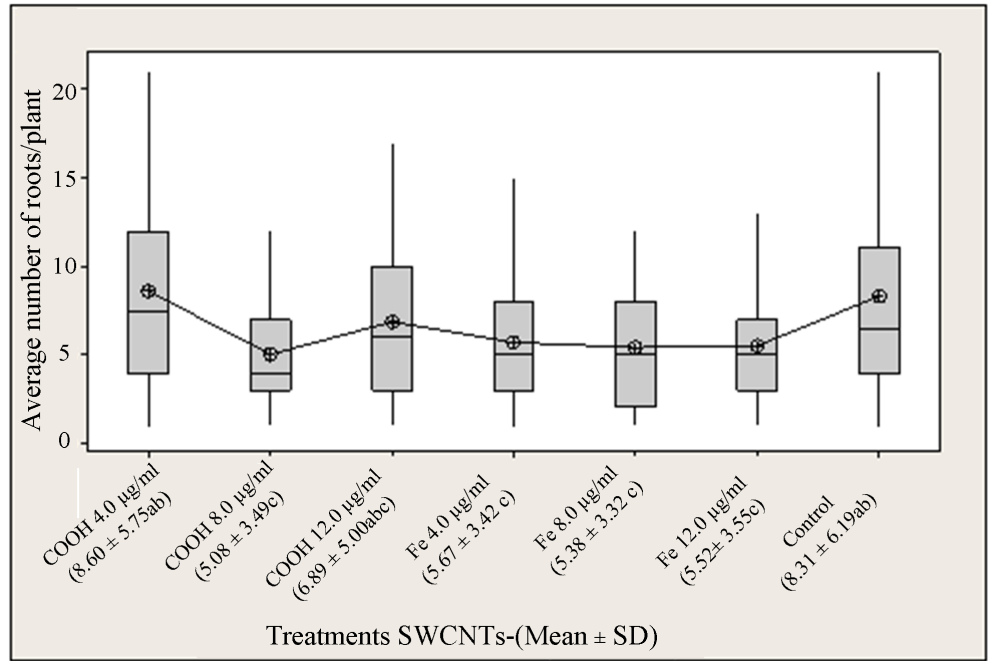

(b)

Figure 2. Evaluated growth and root development variables. (a) Average number of days for root emergence. (b) Average number of roots/plant. Different letters indicate a significant statistical difference between the means of the treatments. Analysis of Variance, Welch's test with a 95\% confidence level ( $\mathrm{p}<0.05)$. Source: Centro de Investigación en Biotecnología ITCR.

rot, cucumber, lettuce, onion, and tomato seeds to concentrations ranging between 56 and 1750 mg/L of functionalized and non-functionalized SWCNTs, establishing that the root elongation was promoted by the lowest concentration of SWCNTs and inhibited at the highest doses, obtaining the best results with non-functionalized SWCNTs. On the other hand, Khodakovskaya et al. [16] evaluated a $50 \mathrm{mg} / \mathrm{L}$ concentration of carboxylated SWCNTs in a culture medium, enhancing tomato seed germination and plantlet growth.

In Figure 2(b) and Figure 3(a), it can be observed that the SWCNTs-COOH assays produced, in average, a higher number of less elongated roots, as well as the control; being contrasted by the results obtained from the SWCNTs-Fe treatments, a desirable condition for the in vitro plant acclimation according to the protocols established in CIB. The positive or negative influence that can be achieved from the CNTs at plant cellular level depends on their length, diameter, and functionalization, and from the either direct or indirect interaction of the molecules that they transport [2]. Khodakovskaya et al. [17] showed that, in general terms, the CNTs can be considered potential growth promoters; since they stimulate genetic and protein expression of aquaporins that facilitate metabolic processes. Nevertheless, this effect can be reduced for non-functionalized CNTs, due to their 


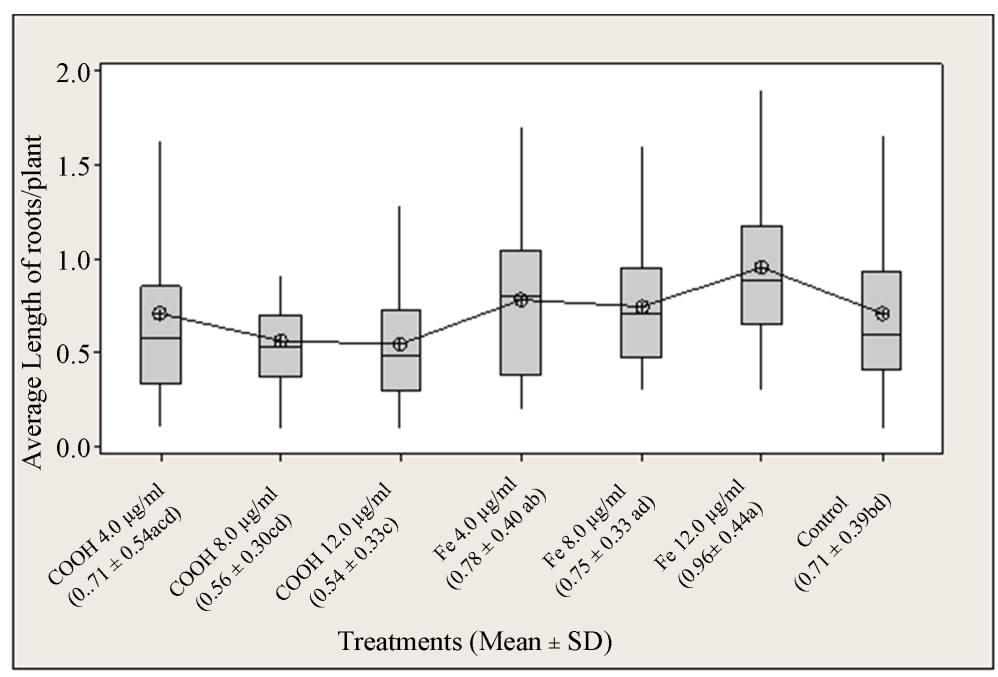

(a)

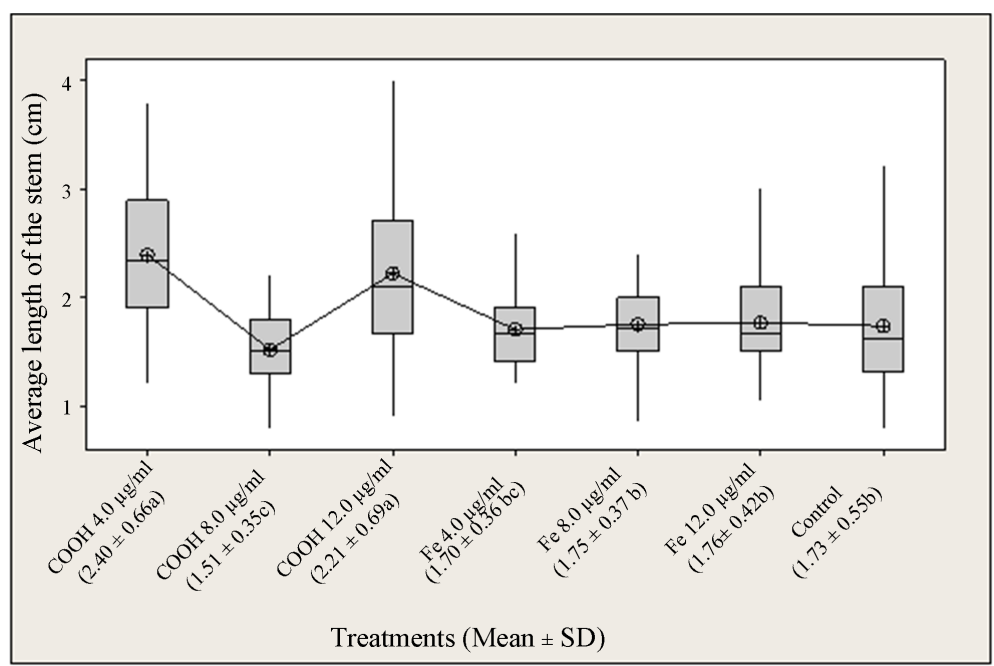

(b)

Figure 3. Evaluated growth and root development variables. (a) Average length of root/plant (cm); (b) Average length of the stem (cm). Different letters indicate a significant statistical difference between the means of the treatments. Analysis of Variance, Welch's test with a 95\% confidence level (p $<0.05)$. Source: Centro de Investigación en Biotecnología ITCR.

higher toxicity effects (Cañas et al. [4], as reported by Husen and Siddiqi [5]).

The characteristics of CNTs will influence absorption, translocation, and interaction with the plant's cell. The CNTs absorption depends on their dispersion within the experimental medium in which they interact [18]. Nonfunctionalized CNTs are difficult to disperse in polar matrices and in water. Hence, they are functionalized before their final use, oxidizing or modifying the hydrophobic surface and improving their dispersion in polar solvents; avoiding their agglomeration in compound matrices and increasing their mobility [2].

For instance, studies related to the SWCNTs dispersion within an ionic liquid medium have determined that they can interact through weak Van der Waals forces [19]. Regarding this previous aspect, there is a possibility that through the addition of SWCNTs in an in vitro culture medium, they establish interactions with the mineral salts the organic acids that compose the medium. Similarly, they could interact with the carbohydrates, where it has been demonstrated that they produce hydrosoluble compounds with enhanced biocompatibility due to the non-covalent interaction (hydrophilic-hydrophobic) in its surface; a mechanism explained by [20].

Additionally, the nanoparticles can be introduced in the plant by their attachment to carrier proteins, through 
aquaporins, using ionic channels, by endocytosis, and through their merge with organic compounds. In the particular case of CNTs, their entrance is associated mainly to the creation of new pores in the cells [18]. A study by Khodakovskaya et al., [16] proposes the hypothesis that CNTs promote water transport by penetrating through the seedcoat. Another entrance path into the plant for small-sized CNTs could be the pores found in the cell wall, which can vary from $2-20 \mathrm{~nm}$, and it is where the ions and water, measuring approximately $0.28 \mathrm{~nm}$, are transported through [21] [22].

In the research carried out by Liu et al. [23] with tobacco cells in suspension, where SWCNTs of a length of less than $500 \mathrm{~nm}$ were applied, it was possible to verify that the nanoparticles were able to enter the cell wall through endocytosis and move towards the cell membranes by a similar mechanism. This process was also reported by Shen et al. [24] in leaf cells of Arabidopsis thaliana, where a typical membrane structure was observed when applying non-functionalized SWCNTs with a length of 5 - $30 \mathrm{~nm}$ and 1 - $2 \mathrm{~nm}$ of diameter.

Once inside the plant, it is likely that the SWCNTs are transported for long distances through its vascular system; however, more evidence is necessary to support this statement [25]. Studies performed by Corredor et al. [26] in pumpkin plants, where carbon-covered iron nanoparticles oriented with magnetism, were applied, evidenced nanoparticle clusters in the cell cytoplasm and in the xylem vessels. On the other hand, it has been evidenced in tobacco and Catharanthus cells that the SWCNTs translocate through the cell wall and the cell membrane [23].

The CNTs singularity of transporting and releasing biomolecules has been proven in numerous research studies related to proteins and nucleic acids, where cell processes interfere, allowing the molecules transported by the CNTs to be available for their transfer into particular organelles [27]-[29].

\subsection{Histological Analysis}

The histological analysis performed through TEM evidenced ultrastructural differences between the control plant tissue and the tissue obtained from plants under the best treatment (Figure 4), with a more differentiated vascular tissue in the samples exposed to the $4 \mu \mathrm{g} / \mathrm{ml}$ SWCNT-COOH treatment. Different research studies have been developed to evaluate the relationship between carbon nanotubes and the transportation and release of biomolecules (proteins and nucleic acids) that enhance cell metabolism [27]-[29]. Hence, a hypothesis has been proposed, suggesting that functionalized CNTs establish interactions with components found in the culture medium, transporting them into the cells; being an interaction that has been proven by Casey et al. [20] in research related to CNTs and starch.

In the control tissue samples, the presence of vascular cambium and the initial differentiation of the xylem tissue is evident; as well as the absence of phloem tissue (Figure 4(A)). In a close up of the xylem vessels, it is possible to observe a considerable amount of cytoplasmic content, a typical trait of an immature xylem cell (Figure 4(B)). On the other hand, the tissue samples from the SWCNTs-COOH $(4 \mu \mathrm{g} / \mathrm{ml})$ treatment show a vascular cambium with mature xylem tissue, and the presence of phloem cells (Figure 4(C)). Additionally, the xylem vessels have developed completely and do not evidence the presence of cytoplasmic content (Figure 4(D)).

It has been considered that the plants rooted with SWCNTs must be monitored for a long term, in order to determine whether it is safe to use CNTs for plant biotechnology application; since the literature reports phytotoxic effects at high concentrations in other species [30]. Shen et al. [24] showed that SWCNTs presented a genotoxic potential in Arabidopsis protoplasts depending on their concentration and size. When these nanoparticles are applied in open systems, the environmental risk should also be assessed, since interactions occur with land and water environments where there is direct contact with fungi, algae, and plants [31] [32]; being the CNTs with impurities (graphite, soot, amorphous carbon, $\mathrm{Fe}, \mathrm{Ni}, \mathrm{Co}, \mathrm{Au}$ and $\mathrm{Pb}$ ) more toxic then those free of impurities [2].

\section{Conclusions}

The SWCNTs-COOH treatments were beneficial for plant growth and rooting. The SWCNTs-COOH assay at a $4 \mu \mathrm{g} / \mathrm{ml}$ concentration presented the shortest average time for root emergence and the plants also had the greatest stem growth.

Furthermore, the TEM analysis evidenced an enhancement in cell metabolism with the stem tissue of plants under the $4 \mu \mathrm{g} / \mathrm{ml}$ SWCNTs-COOH treatment. 

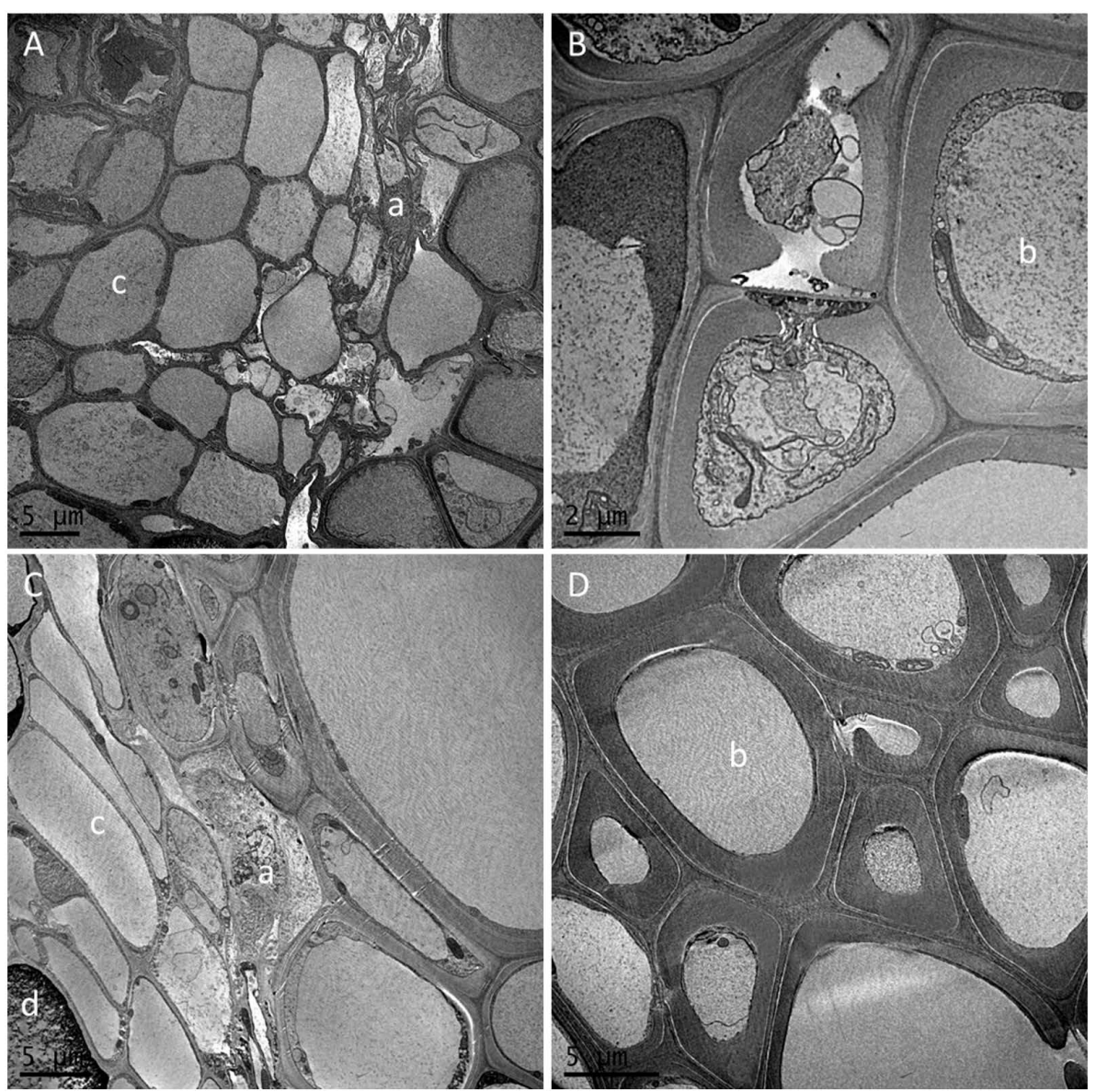

Figure 4. (A) and (B) Control plant tissue. (a) Vascular cambium; (b) Xylem; (c) Parenchyma; (C) and (D) Tissue from plants exposed to SWCNTs-COOH (4 $\mu \mathrm{g} / \mathrm{ml}$ ). (a) Vascular cambium ; (b) Xylem; (c) Parenchyma; (d) Phloem.

\section{Acknowledgements}

The authors would like to thank the Vicerrectoría de Investigación y Extensión of the InstitutoTecnológico de Costa Rica for funding this research.

\section{References}

[1] Ma, X., Geiser-Lee, J., Deng, Y. and Kolmakov, A. (2010) Interactions between Engineered Nanoparticles (ENPs) and Plants: Phytotoxicity Uptake and Accumulation. Science of the Total Environment, 408, 3053-3061. http://dx.doi.org/10.1016/j.scitotenv.2010.03.031

[2] Jackson, P., Jacobsen, N., Baun, A., Birkedal, R., Kühnel, D., Jensen, K., Vogel, U. and Wallin, H. (2013) Bioaccumulation and Ecotoxicity of Carbon Nanotubes. Chemistry Central Journal, 7, 154-175. http://dx.doi.org/10.1186/1752-153X-7-154

[3] Lin, C., Fugetsu, B., Su, Y. and Watari, F. (2009) Studies on Toxicity of Multi-Walled Carbon Nanotubes on Arabidopsis T87 Suspension Cells. Journal of Hazardous Materials, 170, 578-583. http://dx.doi.org/10.1016/j.jhazmat.2009.05.025

[4] Cañas, J.E., Long, M., Nations, S., Vadan, R., Dai, L., Luo, M., Ambikapathi, R., Lee, E.H. and Olszyk, D. (2008) Effects of Functionalized and Nonfunctionalized Single-Walled Carbon Nanotubes on Root Elongation of Select Crop Species. Environmental Toxicology and Chemistry, 27, 1922-1931. http://dx.doi.org/10.1897/08-117.1

[5] Husen, A. and Siddiqi, K. (2014) Carbon and Fullerene Nanomaterials in Plant. Journal of Nanobiotechnology, 12, 16. http://dx.doi.org/10.1186/1477-3155-12-16

[6] Flores, D., Chaves, J., Chacón, R. and Schmidt, A. (2013) A Novel Technique Using SWCNTs to Enhanced Development and Root Growth of Fig Plants (Ficuscarica). NSTI-Nanotech, 3, 167-170. 
[7] Mangir, T., Chaves, J. and Chaves, S. (2008) Impact of CNT Ingestion on In-Vitro Cell. NSTI-Nanotech 2008, 2, 168-171.

[8] Flores, D., Chacón, R., Jiménez, V. and Ortiz, F. (2012) Enraizamiento de mora (Rubusadenotrichos) en medio líquido en el sistema de inmersión temporal y su aclimatación en invernadero. Tecnologíaen Marcha, 25, 3-9.

[9] Çaglayan, K., Serce, C., Barutcu, E., Kaya, K., Medina, V., Gazel, M., Soylu, S. and Caliskan, O. (2010) Comparison by Sequence-Based and Electron Microscopic Analyses of Fig Mosaic Virus Isolates Obtained from Field and Experimentally Inoculated Fig Plants. Plant Disease, 94, 1448-1452. http://dx.doi.org/10.1094/PDIS-11-09-0771

[10] Elbeaino, T., Digiaro, M., Alabdullah, A., Stradis, A., Minafra, A., Mielke, N., Castellano, A. and Martelli, G. (2009) A Multipartite Single-Stranded Negative-Sense RNA Virus Is the Putative Agent of Fig Mosaic Disease. Journal of General Virology, 90, 1281-1288. http://dx.doi.org/10.1099/vir.0.008649-0

[11] Castellano, M., Gattoni, G., Minafra, A., Conti, M. and Martelli, G. (2007) Fig Mosaic in Mexico and South Africa. Journal of Plant Pathology, 89, 441-444.

[12] Swan, A. (2008) Raman Spectroscopy. In: Freiman, E., Hooker, S., Migler, K. and Arepalli, S., Eds., Measurement Issues in Single Wall Carbon Nanotubes, National Institute of Standards and Technology Special Publication, 1960-1978.

[13] Dresselhaus, M.S., Dresselhaus, G., Saitoc, R. and Joriod, A. (2005) Raman Spectroscopy of Carbon Nanotubes. Physics Reports, 409, 47-99. http://dx.doi.org/10.1016/j.physrep.2004.10.006

[14] Jorio, A., Pimenta, M.A., Souza Filho, A.G., Saito, R., Dresselhaus, G. and Dresselhaus, M.S. (2003) Characterizing Carbon Nanotube Samples with Resonance Raman Scattering. New Journal of Physics, 5, 1391. http://dx.doi.org/10.1088/1367-2630/5/1/139

[15] Mondal, A., Basu, R., Das, S. and Nandy, P. (2011) Beneficial Role of Carbon Nanotubes on Mustard Plant Growth: An Agricultural Prospect. Journal of Nanoparticle Research, 13, 4519-4528.

http://dx.doi.org/10.1007/s11051-011-0406-z

[16] Khodakovskaya, M., Dervishi, E., Mahmood, M., Xu, Y., Li, Z., Watanabe, F. and Biris, A. (2009) Carbon Nanotubes Are Able to Penetrate Plant Seed Coat and Dramatically Affect Seed Germination and Plant Growth. ACS Nano, 3, 3221-3227. http://dx.doi.org/10.1021/nn900887m

[17] Khodakovskaya, M.V., De Silva, K., Dervishi, E. and Villagarcía, H. (2012) Carbon Nanotubes Induce Growth Enhancement of Tobacco Cell. ACS Nano, 6, 2128-2135. http://dx.doi.org/10.1021/nn204643g

[18] Rico, C., Majumdar, S., Duarte, M., Peralta, J.R. and Gardea, J.L. (2011) Interaction of Nanoparticles with Edible Plants and Their Posible Implications in the Food Chain. Journal of Agricultural and Food Chemistry, 59, 3485-3498. http://dx.doi.org/10.1021/jf104517j

[19] Wang, J., Chu, H. and Li, Y. (2008) Why Single-Walled Carbon Nanotubes Can be Dispersed in Imidazolium-Based Ionic Liquids. ACS Nano, 2, 2540-2546. http://dx.doi.org/10.1021/nn800510g

[20] Casey, A., Farrell, G.F., McNamara, M., Byrne, H.J. and Chambers, G. (2005) Interaction of Carbon Nanotubes with Sugar Complexes. Synthetic Metals, 153, 357-360. http://dx.doi.org/10.1016/j.synthmet.2005.07.298

[21] Rondeau, C., Defer, D., Leboeuf, E. and Lahaye, M. (2008) Assessment of Cell Wall Porosity in Arabidopsis thaliana by NMR Spectroscopy. International Journal of Biological Macromolecules, 42, 83-92. http://dx.doi.org/10.1016/j.ijbiomac.2007.09.020

[22] Woehlecke, H. and Ehwald, R. (1995) Characterization of Size-Permeation Limits of Cell Walls and Porous Separation Materials by High Performance Size-Exclusion Chromatography. Journal of Chromatography A, 708, 263-271. http://dx.doi.org/10.1016/0021-9673(95)00407-E

[23] Liu, Q., Chen, B., Wang, Q., Shi, X., Xiao, Z., Lin, J. and Fang, X. (2009) Carbon Nanotubes as Molecular Transporters for Walled Plant Cells. Nano Letters, 9, 1007-1010. http://dx.doi.org/10.1021/nl803083u

[24] Shen, C.X., Zhang, Q.F., Li, J., Bi, F.C. and Yao, N. (2010) Induction of Programmed Cell Death in Arabidopsis and Rice by Single-Wall Carbon Nanotubes. American Journal of Botany, 97, 1-8. http://dx.doi.org/10.3732/ajb.1000073

[25] González, P., Fernández, R., Coronado, M.J., Corredor, E., Testillano, P.S., Risueño, M.C., Marquina, C., Ibarra, M.R., Rubiales, D. and Pérez, L. (2008) Nanoparticles as Smart Treatment Delivery Systems in Plants: Assessment of Different Techniques of Microscopy for Their Visualization in Plant Tissues. Annals of Botany, 101, 187-195. http://dx.doi.org/10.1093/aob/mcm283

[26] Corredor, E., Testillano, P., Coronado, M., González, P., Fernández, R., Marquina, C., Ibarra, R., De la Fuente, J., Rubiales, D., Pérez-de-Luque, A. and Risueño, M. (2009) Nanoparticle Penetration and Transport in Living Pumpkin Plants: In Situ Subcellular Identification. BMC Plant Biology, 9, 45. http://dx.doi.org/10.1186/1471-2229-9-45

[27] Lacerda, L., Bianco, A., Prato, M. and Kostarelos, K. (2008) Carbon Nanotube Cell Translocation and Delivery of Nucleic Acids in Vitro and in Vivo. Journal of Materials Chemistry, 18, 17-22. http://dx.doi.org/10.1039/b711554g

[28] Kam, N.W., Liu, Z.A. and Dai, H.J. (2006) Carbon Nanotubes as Intracellular Transporters for Proteins and DNA: An 
Investigation of the Uptake Mechanism and Pathway. Angewandte Chemie International Edition, 45, 577-581. http://dx.doi.org/10.1002/anie.200503389

[29] Kam, N.W., Liu, Z.A. and Dai, H.J. (2005) Functionalization of Carbon Nanotubes via Cleavable Disulfide Bonds for Efficient Intracellular Delivery of siRNA and Potent Gene Silencing. Journal of the American Chemical Society, 127, 12492-12493. http://dx.doi.org/10.1021/ja053962k

[30] Basiuk, V.A., Basiuk, E.V., Shishkova, S. and Dubrovsky, J.G. (2013) Systemic Phytotoxic Impact of As-Prepared Carbon Nanotubes in Long-Term Assays: A Case Study of Parodia ayopayana (Cactaceae). Science of Advanced Materials, 5, 1337-1345. http://dx.doi.org/10.1166/sam.2013.1594

[31] Basiuk, E.V., Ochoa-Olmos, O.E. and De la Mora-Estrada L.F. (2011) Ecotoxicological Effects of Carbon Nanomaterials on Algae, Fungi and Plants. Journal of Nanoscience and Nanotechnology, 11, 3016-3038. http://dx.doi.org/10.1166/jnn.2011.3767

[32] Navarro, E., Baun, A., Behra, R., Hartmann, N.B., Filser, J., Miao, A.J., Quigg, A., Santschi, P.H. and Sigg, L. (2008) Environmental Behavior and Ecotoxicity of Engineered Nanoparticles to Algae Plants and Fungi. Ecotoxicology, 17, 372-386. http://dx.doi.org/10.1007/s10646-008-0214-0 
Scientific Research Publishing (SCIRP) is one of the largest Open Access journal publishers. It is currently publishing more than 200 open access, online, peer-reviewed journals covering a wide range of academic disciplines. SCIRP serves the worldwide academic communities and contributes to the progress and application of science with its publication.

Other selected journals from SCIRP are listed as below. Submit your manuscript to us via either submit@scirp.org or Online Submission Portal.
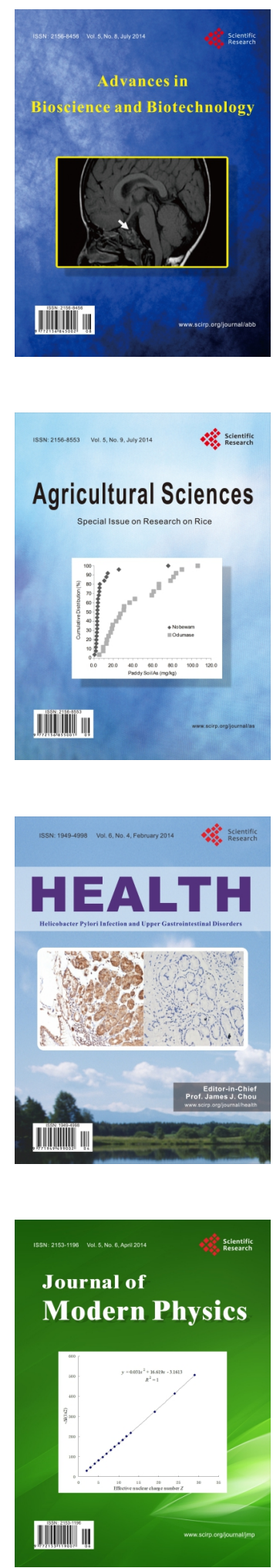
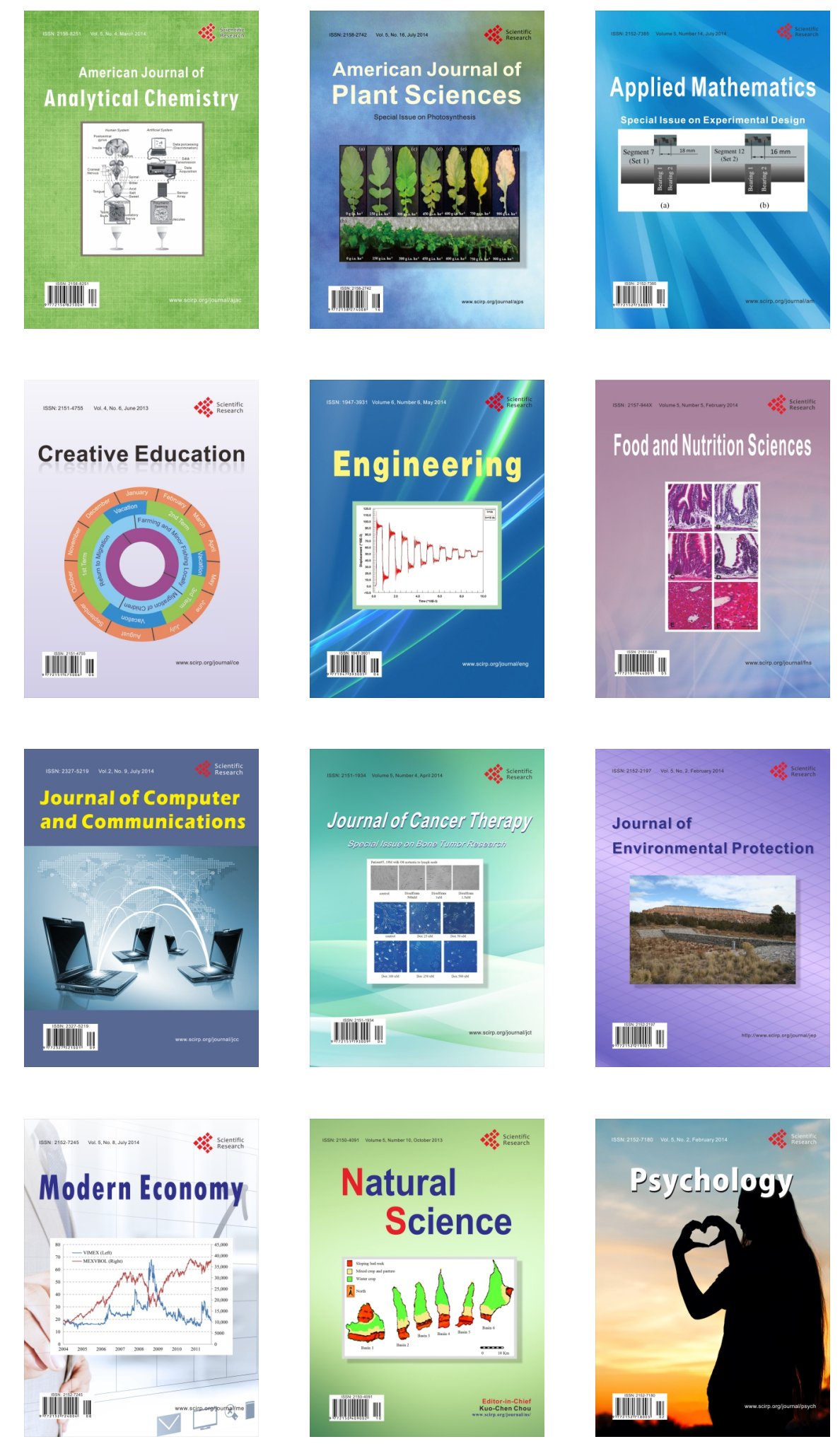